\title{
Message from the Director
}

It is a great pleasure for me to write this message for Turning Points and Transitions: Selections from Southeast Asian Affairs 1974-2018. This volume is one of the major projects that the ISEAS - Yusof Ishak Institute has undertaken this year to commemorate the fiftieth anniversary of the Institute.

Southeast Asian Affairs is an annual review of the politics, international relations and economics of Southeast Asia. Started in 1974, it was the first major publication series undertaken by ISEAS, commencing six years after its birth. It is still the only publication on Southeast Asia of its kind anywhere in the world today.

A glance at the table of contents of Turning Points and Transitions will show chapters on many of the key political, diplomatic and economic developments in the region over the forty-five years covered by the series. Many are authored by prominent scholars and intellectuals of the time, both Asian and Western, with their own individual perspectives.

Needless to say, the editors faced a difficult task selecting 57 chapters out of the 960 in the series. As observed in the Introduction to this volume, they have strived to capture the most important turning points and trends in the rich and eventful history of the region. I think they have succeeded admirably in doing so.

Turning Points and Transitions should be of interest to scholars, students and all others who are curious about the recent history of this region. In a way, it serves as a memory bank for those of us who have lived through those times, to be drawn upon for reflection on how the region came to be what it is today. For the younger generation, it can provide a valuable window into the region's most recent half century of history, which is salient to their understanding of the present.

I thank the editors, Daljit Singh and Malcolm Cook, as well as others who worked with them, for compiling this remarkable volume.

Choi Shing Kwok Director ISEAS - Yusof Ishak Institute 